\title{
Price-Increasing Competition: Evidence from Higher Education
}

\author{
Angela K. Dills* \\ Providence College
}

Kurt W. Rotthoff

Seton Hall University, Stillman School of Business

Affiliated Researcher, Center for College Readiness

Spring 2015

\begin{abstract}
In monopolistically competitive industries, increased competition may lead to price divergence as some firms raise prices to differentiate their higher quality products. We test for priceincreasing competition in higher education using the expansion of for-profit institutions. We observe two-year nonprofits competing directly with for-profits on price. However, we find evidence of price-increasing competition among public schools. As for-profits offering four-year degrees expand, four year public schools raise their paid prices; the largest increases occur at the lowest quality institutions, those that would gain the most by sending a quality signal. This increase in paid price allows the public schools to segment the market and capture the more price-inelastic students.
\end{abstract}

JEL Classifications: L11, I23

Keywords: higher education, tuition, for-profits, price-increasing competition

\footnotetext{
* Angela Dills at: adills@providence.edu, Providence College, 1 Cunningham Square, Providence, RI 02981. Kurt Rotthoff at: Kurt.Rotthoff@shu.edu or Rotthoff@gmail.com, Seton Hall University, JH 674, 400 South Orange Ave, South Orange, NJ 07079. A special thanks to Rey Hernández-Julián, Robert Hammond, Frank Limehouse, Jennifer Kohn, Leo Kahane, seminar participants at the University of Colorado-Denver and Lafayette College, and the participants at the 2013 annual meetings of the Eastern Economic Association and 2014 Southern Economic Association for helpful comments. Any mistakes are our own.
} 


\section{Introduction}

In an industry where products differ in quality or characteristics, the effect of entry on the price of existing products is unclear. Goods that directly compete with the new entrant likely respond with lower prices. Conversely, goods in the same market that are not in direct competition may respond with a price increase. Chen and Riordan (2008) term this latter effect 'price-increasing competition' and provide its theoretical foundation: firms that have a differentiated good respond to entry differently than those that are direct competitors.

An excellent example of this may be found in the U.S. education market. In recent decades there has been a surge in for-profit education institutions. For-profits are commonly thought to compete directly with lower-quality non-profit institutions. The impact of for-profit competition on higher-quality institutions is less clear. With price-increasing competition, we expect firms offering higher quality products to increase their price, signaling their quality difference and segregating the market. This is the hypothesis examined within this study: do higher-quality educational institutions respond to the entry of for-profit institutions? And, if so, do they show evidence of price-increasing competition?

Currently, the higher education industry is characterized by two main trends: significant tuition increases and rapid expansion of student enrollment in for-profit institutions. Average real sticker price (in 2009 dollars) has risen from $\$ 7,923$ in 1990 to $\$ 14,603$ in 2009, an 84 percent increase. ${ }^{1}$ Meanwhile, enrollment in for-profit institutions has almost doubled, rising from 4.5 percent of students in 1990 to 8.9 percent in 2009. Although these trends are often interpreted independently, we hypothesize that there is a connection. For-profit education creates competition for existing schools. This competition will have a differing impact on schools that directly compete against for-profits and schools that are typically thought to be of higher

\footnotetext{
1 Authors' calculations from DCP IPEDS data. We omit 7 outliers with real net tuition from students per FTE over $\$ 100,000$. We also omit data from the Mid-America College of Funeral Service whose data are also outliers. These outliers do not appear in the estimation sample used in the analysis below.
} 
quality and thought to not care about the for-profit entry. We posit that the former will lower prices to compete directly with for-profits, while the latter will increase prices to signal their higher quality; thus, showing signs of price-increasing competition.

In the next section we discuss the theoretical underpinnings of price-increasing competition. Section three provides some background on higher education and modern tuition increases. We document the well-known rise in college tuition and illustrate the enrollment growth in for-profit institutions. Section four details the empirical model and section five describes the data. We separate schools into two- and four-year institutions, expecting the type of institution to impact the pricing response of that institution. The Delta Cost Project (DCP) cleaned and collated panel data from the Integrated Postsecondary Education Data System (IPEDS). We use their data on tuition paid, list price, and college characteristics to estimate a model on how prices change at schools based on enrollment in for-profits over the previous year. In some specifications, we allow the pricing response to differ for entry by two-year and four-year for-profit schools. We also model the pricing impact of for-profit entry on schools that are categorized as low-, mid-, and high-quality where quality is measured by the fraction of applicants who are admitted and faculty-student ratio.

We find evidence of price-increasing competition in the U.S. higher education market. High quality public schools respond to an expansion of for-profit enrollments by increasing their sticker prices, plausibly to differentiate their product. They also increase the real price paid per student, likely due to increasing out-of-state students. Two-year private nonprofit schools lower list prices in responses to the expansion of for-profits while four-year private nonprofit institutions do not appear to respond. Section six describes the results and section seven analyzes the different impact of for-profit entry on low-, mid-, and high-quality institutions. Section eight presents a variety of robustness checks. The last section concludes. 


\section{Price-Increasing Competition}

Suppose you are the only lemonade stand in town. Another lemonade stand enters the market directly competing with you. In a competitive industry without product differentiation, new firms shift the supply curve rightward, lowering price. Entry in other market structures, however, is more complex. For example when firms offer heterogeneous products in a monopolistically competitive industry, you have three possible responses: lower your price to compete directly, offer a product that is so distinct that your product is independent of their entry, or raise your quality and offer a distinct product at a distinct price (organic lemonade!). This means entry can lower or raise prices of the existing firms. This is especially true when there is a divergence in the quality being offered by the different groups.

There are at least four ways entry may affect a monopolist. A firm with higher prices may use that price to signal their high-quality goods to consumers (Monroe, 1973; Bagwell and Riordan, 1991). Chen and Riordan (2008), for example, analyze three additional ways entry may affect a monopolist. First, a duopolist may differentiate its product to separate consumers by their willingness to pay. Entry leads to price divergence between two goods of differing qualities. $^{2}$ Second, entry of the second firm may steepen the demand curve faced by the duopolist. This price sensitivity effect of entry reduces the benefit of lowering prices; entry can lead firms to raise prices. The elasticity response is not fast; Ching (2010) finds that consumers' risk-aversion slows their move to an unknown product. Third, the original firm may decrease price in response to entry to keep its market share as high as possible. This market share effect differs from the previous two effects in that entry leads prices to decrease.

For simplicity assume that quality is either high or low. With both high and low quality firms in the market, their pricing response to competition can differ and will depend on the

\footnotetext{
${ }^{2}$ Ward et al. (2002) discusses similar price-increasing competition in a multi-firm model including costly quality improvements and a reduced need to appeal to more distant consumers.
} 
quality of the entering firm. Price-increasing competition occurs when high quality firms increase their price in response to the entry of a low quality firm. The higher price reflects the higher quality of their products.

Most evidence on price-increasing competition stems from the pharmaceutical market. Scherer (1993), for example, displays the established phenomenon of the "Generic Competition Paradox": as a brand-name drug loses its patent and generic drugs enter the market, the price of the brand-name drug increases instead of decreases (Caves, Whinston, and Hurwitz, 1991; Frank and Salkever, 1992, 1997; Grabowski and Vernon, 1992; Hurwitz and Caves, 1988; and Kong 2004, 2009). The brand name of first movers allows product differentiation and permits retail brands to charge higher prices (Schmalensee, 1982 and Scherer and Ross, 1990). ${ }^{3}$ Ward et al. (2002) expand this research by finding price-increasing competition as private-label food products enter the market at grocery stores. As entry of private-label food products occurs, name-brand products respond by increasing prices. Similarly, Courtemanche and Carden (2014) find that existing grocery stores raise prices following the entry of Costco in the city. Our analysis further expands empirical tests of this theory by analyzing the entry of for-profit institutions in higher education.

\section{The Higher Education Industry}

\section{A. The rise of for-profit institutions}

Of the 4,495 degree-granting colleges and universities in the United States, more than half (62 percent) are four-year colleges and universities. The remaining 38 percent are two-year

${ }^{3}$ Scott Morton (2000) finds that this difference in price is not a result of the brand advertising. 
institutions. ${ }^{4}$ Within each of these degree-granting categories, there are public institutions, nonprofit private institutions, and for-profit private institutions.

Since 1990, the number of institutions has increased across almost all categories. Public colleges and universities increased from 1,567 to 1,672, mostly as a result of new four-year institutions. The experience of private, non-profit institutions differs for four-year and two-year schools. Four-year, private, non-profit institutions increased from 1,482 to 1,539 although twoyear, private, non-profit institutions decreased from 167 to $85 .{ }^{5}$

The largest increase has come from for-profit schools. The 856 net new for-profit institutions comprise 499 four-year schools and 357 two-year schools. Figure 1 illustrates the fraction of students enrolled in for-profit institutions. For-profit enrollment steadily increased between 1990 and 2001. Since 2002, for-profit enrollment has increased more rapidly.

In 2009, 62 percent of for-profit institutions were two year schools, although 74 percent of students in for-profit institutions were enrolled at four-year schools. Many for-profit institutions are beauty schools, art schools, and information technology- and electronics-focused schools. These degrees may differ substantially from four year non-profit schools although they overlap with those offered at many community colleges and two-year institutions. Most students at for-profit schools seem to be enrolled in four-year programs primarily focusing on professional degrees (business, health care, IT, etc.). Non-traditional aged students are more likely to enroll in a for-profit institution. ${ }^{6}$

\section{B. Trends in higher education tuition}

Much attention has been drawn to the rising price of attending college. Figure 2 illustrates the rising tuition in our sample. In-state tuition and fees is the listed price of

\footnotetext{
4 Data from Table 275 of the Digest of Education Statistics, 2010 (U.S. Department of Education, 2011).

${ }^{5}$ We observe more two-year private non-profit institutions leaving the sample in areas with more expansion of for-profit enrollments.

6 See Deming et al. (2012) for a more detailed description of for-profit institutions.
} 
attending the institution for an in-state resident or, in the case of private schools, for all students. We present the inflation-adjusted "sticker price" in-state tuition and fees for 1990 through 2009. Between 1990 and 2009, the real sticker price increased from $\$ 8,115$ to $\$ 14,771$ (in \$2009 dollars), a real increase of 82 percent. The second series in the figure illustrates the growth rate of sticker price during these years. In all years, the real growth rate was positive, exceeding 2 percent in most years. As figure 2 illustrates, tuition costs rose 3.2 percent faster than inflation each year, on average, between 1990 and 2009.

Most students, however, do not pay list price (Baum and Ma, 2011). The sticker price of higher education differs from the price paid by the students attending by the amount of any scholarships and grants. In Figure 3 we graph three measures of the price of college: the sticker price from Figure 2, the net tuition per full-time equivalent (FTE) student, and the net tuition from students per FTE student. Net tuition per FTE student is the sticker price less any institutional grants or scholarships. It includes grants and scholarships provided by external organizations including federal grants such as the Pell Grant used to pay tuition. Net tuition from students per FTE student is the amount paid by the student directly or through loans. ${ }^{7}$ Tuition revenue per student and tuition paid per student increased by similar amounts over this period, by 58 and 55 percent. In all cases, these prices have risen about 3 percent faster than inflation per year, although students on average pay about 63 percent of the list price.

\section{Existing explanations for rising tuition in higher education}

The rising price of college has attracted significant research attention over the years. Price increases may stem from increased demand, increased costs of providing education, and changes in market structure and government policy. We briefly present the many different

\footnotetext{
${ }^{7}$ Sticker price is constructed from the in-state tuition and fees for full-time undergraduates. Net tuition per FTE student is net tuition divided by
} reported FTEs. Net tuition from students per FTE is net tuition from students divided by reported FTEs. 
existing explanations for this observed increase in tuition before exploring the idea of priceincreasing competition.

Demand-side evidence in the literature includes increased returns to schooling. Since 1980, the U.S. economy has experienced a significant increase in the monetary returns to postsecondary education (Autor, Katz, and Kearney, 2008; Goldin and Katz, 2008). The increase in the monetary benefits of an education has been paired with an increase in the sticker price of college and in aid awarded to students. Colleges have also increased spending on consumption good aspects of higher education such as dormitories, significant predictors of students' college choices (Jacob, McCall, and Stange, 2013). Given the pricing structure and spending of a school are driven by the students' preferences, these impacts also increase the price of schooling in general.

Rising costs of providing higher education have also contributed to tuition increases. Some of this literature focuses on Baumol's cost-disease: how labor-intensive, non-traded goods such as higher education benefit little from technological improvements (Baumol and Bowen 1966 and, more recently, Baumol 2012). Ehrenberg and Murphy (1993) discuss the different impacts that drove up the tuition prices in the 1980 os by looking at faculty salaries, endowments, physical plant costs, library costs, computerization, governmental support, recruitment, and financial aid. Ehrenberg (2007) outlines several others including the quest for prestige, the end of mandatory retirement, student life, and shared governance.

Changes in the market and government policy have also influenced tuition. The Bennett hypothesis states that as government subsidies increase, schools raise their prices (Bennett 1987). This hypothesis finds some support in the literature such as Singell and Stone (2007) and Cellini and Goldin (2012). Rising tuition allows more room for schools to separate out the total cost of attending and the expected family contribution, increasing schools' ability to price discriminate. When the list price increases, but the paid price does not, the school can charge the highest willingness-to-pay individuals a higher price. This higher price to a certain group of 
individuals allows the school to lower the price to other groups such as higher achieving students (as in Rothschild and White, 1995), access to those that cannot afford the school, or some combination of both. This allows for more effective recruiting of high quality applicants (McPherson, Schapiro, and Winston, 1993; Cornwell, Mustard, and Sridhar, 2006; and Nielsen, Srensen, and Taber, 2010).

Hoxby (2009) shows that one of the larger changes in the educational market has been from local autarkies to an integrated national market. Hoxby (1997) notes that colleges losing market power are competing on quality and raising prices, which follows the argument in Ward et al (2002) for costly quality improvements. She highlights the role played by an "increasingly geographically-integrated college market” facing all higher education institutions. Hoxby (2009, Figure 2) illustrates the widening variance in expenditures per pupil across schools of varying selectivity, suggesting some quality improvements as the industry became more competitive. We expand this research by focusing on the specific role of for-profit institutions. Further, although Hoxby discusses competitive effects in terms of average price charged, we separate out the pricing impact for institutions of varying quality.

\section{Higher education and the possibility of price-increasing competition}

The higher education industry is monopolistically competitive: colleges and universities differentiate themselves from their competitors who are geographically or characteristically close. Colleges and universities historically have established a brand name, including the reputation of producing graduates of a certain quality. Risk-averse consumers may be willing to pay more for a high quality institution with an established brand name and school quality matters to students. Students at higher quality institutions learn more (Dills and HernandezJulian, 2008), are more likely to go on to graduate school (Eide et al., 1998), and, as graduates, earn more money (Black and Smith, 2006; Behrman et al., 1996). 
Firms can either disclose quality or signal quality through price (Daughety and Reinganum, 2008). In higher education, the disclosure of quality is difficult. Upon matriculation to or graduation from a college, it is hard to measure the true impact of its education. Schools can, however, use tuition to signal quality. ${ }^{8}$ In the book, Tuition Rising, Ehrenberg (2002) states that

"[The schools] have been able to do this in part because of the belief that in the higher education market, posted price (tuition and fees) is taken by many to be an indicator of quality; if an institution lets its tuition fall relative to its competitors it runs the risk of being perceived as an inferior institution."

Below, we test for price-increasing competition in higher education. We focus on the price impact of an institution when there is increased penetration of for-profit schools. Deming et al. (2012) document the low quality of for-profits compared to community colleges, although Cellini and Chaudhary (2012) and Lang and Weinstein (2013) find contrasting results. Both, however, suggest that community colleges and for-profit institutions compete directly for students. If price-increasing competition exists, we would expect the high quality schools to increase their prices when there is increased entry of for-profit schools.

\section{Empirical Model}

To test for price-increasing competition in the education market we use Ordinary Least Squares to estimate the following for institution $i$ in Core Based Statistical Area (CBSA) $c$ at time $t:$

$$
\begin{gathered}
\ln \left(\text { Tuition }_{\text {ict }}\right)=\alpha \ln \left(\% \text { inForProfit }_{\mathrm{ct}}\right)_{\mathrm{t}-1}+\beta \ln \left(\% \text { inForProfit }_{\mathrm{ct}}\right)_{\mathrm{t}-\mathrm{t}}{ }^{*} \operatorname{low}_{\text {quality }} \text { ict } \\
+\mathrm{X}^{\prime} \gamma+\phi_{\mathrm{i}}+\tau_{\mathrm{t}}+\delta_{\mathrm{i}} \mathrm{t}+\varepsilon
\end{gathered}
$$

\footnotetext{
8 In Fall 2004 Miami University (Ohio) increased the in-state tuition rates to equal the out-of-state tuition rates, then provided scholarships to the in-state students to mitigate this increase. This move was designed to help in-state students understand the quality of schooling they were receiving (Bowman and Bastedo, 2009).
} 
In equation 1 we consider two primary dependent variables: the sticker price and the tuition paid per student. ${ }^{9}$ Our focus is on the effect of for-profit enrollment on tuition. We measure for-profit penetration using the fraction of students in a CBSA enrolled in a for-profit school over the past year. The use of lagged for-profit enrollment allows for the timing of institutions' tuition setting. ${ }^{10}$

One practical difficulty here is defining the 'market' with which an institution competes. Census-defined CBSAs comprise metropolitan and micropolitan statistical areas. The Census Bureau defines a metro area as "a core urban area of 50,000 or more population" and a micro area as "an urban core of at least 10,000 (but less than 50,000) population.” A CBSA includes the counties "containing the core urban area" and "any adjacent counties that have a high degree of social and economic integration” (U.S. Census Bureau, 2013). We omit all institutions not in a CBSA.

Although Hoxby (2009) documents the nationalization of the market for higher education, most institutions are less selective or not selective and enroll primarily local students. Even among students taking on-line courses, 35 percent of which are enrolled in for-profit institutions, most register for classes with institutions within 100 miles of their residence (Aslanian and Clinefelter, 2012, p. 13, 20). For-profit enrollments are influenced by local community college tuition (Chung 2012) as well as the passage of local community college bonds (Cellini 2009). This literature supports the argument that colleges compete within local geographic markets. McMillen et al. (2007) provide spatial evidence that colleges compete on price with institutions located geographically close. As such we define the market as the CBSA.

\footnotetext{
9 A practical difficulty is that, although sticker price is always positive, in about 10 percent of the sample, the tuition paid per student is negative. This is due, for example, to schools receiving appropriations that cover many costs of operations and students receiving scholarships and grants that exceed the sticker tuition price where the excess covers, for example, housing. Taking logs of these figures drops them from the sample. We estimate the regressions using the level of tuition or net price with the full sample and find qualitatively similar results. However, the results below only include the observations with positive net prices.

${ }^{10}$ Lagging the for-profit enrollment two years produces similar results as those presented.
} 
Concentration ratios (see Demsetz 1973 and Peltzman 1977) are used to measure how much influence a given number of firms have on an industry. ${ }^{11}$ The first published study using price as the dependent variable, focusing on a competition measure (such as a concentration ratio), was Kessel (1971). The industry structure/price relationship has been analyzed in many studies since then; see Marvel (1978), Aspinwall (1970), Geithman, Marvel, and Weiss (1981), Lamm (1981), Stavins (2001), and Gerardi and Shapiro (2009).

We continue this research and measure competition from for-profits as the percentage of students in a CBSA that are enrolled in a for-profit institution. We measure this concentration as for-profit schools enter an area with an existing stock of nonprofit schools. Given that we would like to measure the impact of for-profit enrolments, the percentage of students enrolled in forprofit institutions captures a form of a concentration ratio between the for-profit and nonprofit enrollments within that CBSA. This use of enrollments captures more than the number of institutions, particularly given the large increases in student body size that many for-profits experience. This follows work by Putsis (1997), who looks at private label penetration, as measured by total private label share, finding that the average price of national brands decrease. Keeler, Melnick, and Zwanziger (1999) look at the association of hospital prices with measures of market concentration, finding that prices are higher in less competitive areas (even for nonprofit hospitals).

We allow the effect of for-profit enrollment to differ based on the quality of the institution. High quality schools may respond to the entry of low quality schools by raising price, raising quality, or both. Low-quality schools likely respond to the entry of other low quality schools by lowering price. ${ }^{12}$ With price-increasing competition, we expect the coefficient on forprofit enrollment to be positive and the coefficient on the interaction term to be negative.

\footnotetext{
11 The often used Herfindahl-Hirschman Index (HHI, Hirschman 1964) makes less sense in this setting given that we are comparing the market impact between two types of institutions.

12 Whether schools respond by increasing quality is beyond the scope of this paper, although an interesting question for further research.
} 
We categorize institutions by quality in two ways. First, we use the type of institution as an indicator of quality, allowing for-profit entry to affect four-year colleges and universities differently than two-year colleges. We expect two-year institutions to compete more on price, lowering tuition in response to entry at the same time as four-year institutions raise their price to signal their high quality. Second, we generate a quality index. Black and Smith (2006) use "five measures of [college] quality: faculty-student ratio, the rejection rate among those who applied for admission, the freshman retention rate, the mean SAT score of the entering class, and mean faculty salaries." We use two of these measures. We do not have SAT scores for open enrollment schools and retention rates are less relevant for two-year schools because a large number of students transfer to other institutions. Faculty salary is also missing for many observations. ${ }^{13}$ The index is the principal component of two variables: the fraction of applicants who are admitted and faculty-student ratio. ${ }^{14}$ Because values for these variables are missing for a large fraction of the sample, we emphasize the results using degree type as the quality measure.

In specifications using the quality index, we categorize institutions into low, middle, and high quality schools using the 25th and $75^{\text {th }}$ percentile of institutions' average school quality index during the period. Schools with an average below the 25th percentile are labeled low quality, high quality schools are above the $75^{\text {th }}$ percentile, and middle quality schools are the middle 50 percent. High quality schools range from Framingham State College and Wichita State University at the low end of high quality to Harvard, Princeton, and Stanford at the top end. ${ }^{15}$ Based on our index, low quality schools range from O’More College of Design and New Life Theological Seminary to City University and Clearwater Christian College. ${ }^{16}$ The top tranche

\footnotetext{
13 Results are similar using an index comprised of these two measures as well as faculty salary although it drops many lower quality schools from the sample.

14 The index, however, is highly correlated with SAT scores. For the SAT, the correlation with the 75th percentile in math is $0.65 ; 25$ th percentile in math, $0.71 ; 75$ th percentile in verbal, $0.56 ; 25$ th percentile in verbal, 0.63 (all p-values $=0.0000$ ).

15 On our index, Framingham State College averages 0.295; Wichita State University, 0.28; Harvard, 3.2; Princeton, 2.9; and Stanford, 3.

16 On our index, O’More College of Design averages -1.1; New Life Theological Seminary, -2.2; City University, -0.67; Clearwater Christian College, -0.7 .
} 
of institutions incorporates most, 70 percent, four year selective (not open enrollment) institutions.

We control for a vector, $\mathbf{X}$, of CBSA-specific variables including the unemployment rate, real per capita income, the fraction of the population that is Hispanic, and the fraction of the population aged 15 to 24 . These variables are constructed by aggregating county-level data provided by U.S.A. Counties to the CBSA-level.

The empirical specification includes institution fixed effects, $\phi_{\mathrm{i}}$, and year dummies, $\tau_{\mathrm{t}}$. Institution fixed effects control for the average quality of the institution over time and its typical pricing behavior. The yearly fixed effects capture time variation common to all institutions. For example, all three types of schools qualify for government sponsored grants and loans. Annual fixed effects capture nationwide changes in the changes in federal aid policies, cost of labor common to all institutions, and, for example, nationwide changes in the returns to schooling. As Hoxby (2009) describes, competition in higher education has increased since about the 1970 s as transportation and communication costs have fallen. Falling airplane ticket prices, cell phones, and the expansion of the internet facilitate student enrollment far from home. The year dummies capture any national changes in competition over time.

We also include CSBA-specific time trends. These CBSA trends capture any area-specific changes in tuition-related competition. They also account for any trend in the average tuition in a CBSA that may attract entry. Standard errors are clustered by CBSA.

We estimate this model separately for public and private, non-profit institutions. Public institutions, for example, rely on state and local financing for operating expenses; political considerations, in many cases, determine public tuition rates. We omit for-profit schools from the sample since the entrants we analyze are for-profit entrants. We also estimate the response of entry by two- and four-year for-profit institutions separately, postulating that two-year forprofits more closely compete with two-year institutions on price as they provide more similar products than do two- year and four-year institutions. We also, separately, measure the impact 
of for-profit entry on high- and low-quality institutions. This separation allows us to measure the possibility that low-quality schools are more likely to compete with for-profit schools than high-quality schools.

Our focus is on the impact of for-profit institutions' expansion into a market and how it influences the tuition charged at institutions of varying quality the following year. If the estimate of the coefficient, $\alpha$, is positive, that suggests the presence of price-increasing competition as entry leads high quality schools to increase their price as they compete on brand-name. As there is a difference in quality, risk-averse consumers will have an increasing willingness to pay for an institution with an established brand-name. Price-increasing competition may also imply a negative estimate for the coefficient, $\beta$, as low quality schools decrease their price to compete for market share.

\section{Data}

The Delta Cost Project (DCP) assembled panel data from the Integrated Postsecondary Education Data System (IPEDS). We use their data for 1990 through 2009. IPEDS is administered by the National Center for Education Statistics and, under the authority of the Higher Education Act of 1965, collects data on all institutions of higher education participating in federal financial aid programs (National Center for Education Statistics, 2013). The DCP data set contains detailed revenue and expenditure data as well as information on typical measures of school quality. Each institution is also matched to a core-based statistical area (CBSA). Although highly selective institutions compete nationally, most institutions are less selective or open enrollment and compete more locally. ${ }^{17}$ Effects due to increased national competition are subsumed in the year fixed effects.

\footnotetext{
17 The top tier schools are more likely to have a national draw, rather than a local (or CBSA) draw. In the robustness section, we drop the top 1 percent of schools as well as further down the distribution.
} 
Our sample comprises institutions of higher education that offer two-year and four-year degrees. This likely understates the number of for-profit two year and less than two year institutions in the market (Cellini and Goldin, 2012). Underestimating the frequency of lower quality entrants would tend to bias upwards any estimated effect of for-profit entry on tuition. We exclude medical schools, theological seminaries, administrative units, and less than two year institutions. ${ }^{18}$

For-profit schools can have large national chains. As an example, in our sample, the University of Phoenix has 61 campuses in 59 CBSAs, all four-year for-profit schools. In our sample, ITT Tech has 102 campuses in 85 CBSAs, about 70 percent of which are four-year schools. Although not all for-profit schools are low-quality, the average quality of for-profit schools is low. Using our mean zero principal components index, for-profits' average quality is 0.77, about three-quarters of a standard deviation below the mean. ${ }^{19}$ In comparison, in our sample of nonprofits and public schools, two year schools average a -0.02 on our quality index; four-year schools average 0.26 , one third of a standard deviation higher on our quality index. ${ }^{20}$ Thus, the use of for-profits as a proxy for entry of low-quality competition is consistent with the literature.

Figure 4 graphs the different tuition types for public and private, non-profit four-year institutions. Tuition is lower among four-year public schools than their competing private schools. Tuition increased for both types of schools, with sticker price rising at least as rapidly as paid price. Sticker price and paid price at public schools increased 107 percent over these 20

\footnotetext{
18 Institutional sectors such as 'less than two year' are defined using the DCP's "sector-revised" variable. We exclude those with the Carnegie Classification (2000) of "Medical schools and medical centers". Further excluding the category "Other separate health profession schools" produces similar results. We also exclude 7 observations where the tuition paid by student per FTE exceeds $\$ 102,000$. Scanning these 7 schools' time series of net tuition shows these 7 observations as clear outliers.

${ }^{19}$ We estimate similar regressions using the fraction of students enrolled in low-quality institutions as the right hand side variable of interest. The results are qualitatively similar and available upon request.

20 The means are statistically different from each other ( $\mathrm{p}$-value $=0.0000$ ) but note that some two year institutions do not have information on the variables used to construct the quality index. As such, they are not included in these means.
} 
years. ${ }^{21}$ At private four-year schools, sticker price increased 78 percent while paid price increased 47 percent between 1990 and 2009. The gap between list and paid price is smaller for public schools.

Table 1 provides the summary statistics for the data and controls used in our study. Tuition and required fees, in inflation-adjusted 2009 dollars, average $\$ 11,297$ in the full sample with net price averaging $\$ 7,563$. On average, $6.3 \%$ of students in a CBSA are enrolled in a forprofit, although this ranges from o to 74.3 percent. $^{22}$

There is significant variation across CBSAs in enrollment growth between 1990 and 2009. Some CBSAs experience significant declines in for-profit enrollment during the sample period (for example, York-Hanover, PA and Utica-Rome, NY). In other CBSAs, such as Santa Rosa, CA and Orlando-Kissimmee-Sanford, FL, for-profit enrollment increases significantly. Still others like Little Rock-North Little Rock-Conway, AR and Helena, MT found themselves with similar for-profit shares in 1990 and in 2009. Averaging across CBSAs, for-profit enrollment increased by about 79 percent with a standard deviation of 1.3 log points.

\section{Results}

We first consider the pricing responses of two- and four-year institutions. Table 2 presents the results for OLS estimates of equation (1) to test for price-increasing competition. Private nonprofit two-year and four-year schools do not change list price in response to forprofit enrollments (column 1); neither do they change paid price (column 3). Among public schools, however, four-year schools increase their real sticker price (column 2) and the price paid by students (column 4). Higher quality public schools respond to competition with price increases. Prices at two year public schools do not respond to for-profit enrollment as the sum of

\footnotetext{
${ }^{21}$ Some public schools have shifted their recruiting efforts to recruit more out of state students which pay higher tuition rates (Rizzo and Ehrenberg 2004). For this reason, some schools in the sample have a net price higher than the list price.

22 There are two observations have surprisingly large tuition figures. The results below do not change significantly when we exclude these observations.
} 
the coefficients on the interaction term and the enrollment variable is small and not statistically different from zero.

Two-year and four-year for-profit institutions may impact the higher education market in different ways. In Table 3 we separate out enrollments in for-profit institutions by two- and four-year schools. We again find results supporting the hypothesis of price-increasing competition, at least among public schools. Table 3 shows that public schools increase their sticker price with the penetration of two-year for-profit enrollments (column 2). Public two year schools, however, seem to compete directly with for-profit four-year schools, lowering stickers prices in response to for-profit expansion. Paid prices at public schools also respond to the expansion of for-profit four-year enrollments: four year public schools by raising paid prices and two year public schools by lowering paid prices. These price responses are consistent with price increasing competition as higher quality firms segment the market by the price elasticity of demand. Private, non-profit schools respond only to four-year entry: two-year nonprofits lower list prices and four-year nonprofits maintain list prices (column 1).

As more low quality schools enter a market, the marginal value of receiving a degree from a high-quality school increases. We find that public four-year schools increase their list price, to signal the quality difference, and paid price to capitalize on the increased value of highquality schooling. Public schools may increase paid price by reducing institutional aid as well as by admitting more students from out-of-state, who pay higher tuition rates than in-state students. ${ }^{23}$ This allows private schools to attract higher quality students as theorized in Rothschild and White (1995).

A typical concern with price regressions is whether for-profits enter into MSAs due to, for example, rising prices by their competitors. This behavior would bias our estimates on forprofit expansion upwards. It seems reasonable, however, to expect that for-profits would focus

\footnotetext{
${ }^{23}$ In fact, regressing the fraction of students from out-of state on for-profit enrollment suggests that increasing out-of-state enrollment is one response from public schools.
} 
more on the tuition charged by their nearest competitors: two-year public schools or lower quality four year schools. Our results suggest that these schools are lowering their prices in respond to the entry of for-profits. An upward bias implies that lower quality nonprofits likely price compete more directly. Further, the effect on higher quality schools differs from that of lower quality schools (below); any bias seems likely to affect these two coefficients the same or, if anything, to further bias upward the coefficient for lower quality schools as compared to that for higher quality schools.

\section{Separating by Quality}

Up to this point we have analyzed the difference in price response to entry by two- and four-year schools. In this section we change the focus on the difference in low-, mid-, and highquality schools.

Table 4 presents the results for sticker price at private nonprofit schools in column 1 and public schools in column 2. The estimates in column (1) suggest that middle and high quality schools have little change in their sticker price; the sum of the enrollment term and the interaction term for high quality is small and statistically insignificant. Low quality private schools may respond by lowering stickers prices although the coefficient is not statistically different from zero. In column 2, we observe a statistically significant increase in sticker price for high-quality public schools (column 2) and a large decrease in sticker price for low quality public schools. The estimates in columns (1) and (2) suggest that high quality public institutions respond with higher sticker prices while high quality private institutions do not change their sticker prices. Low quality public nonprofits, however, lower their sticker prices in response to for-profit entry. These results may be consistent with price-increasing competition.

Results examining the real price paid appear for private nonprofit schools in column 3 and public schools in column 4. We observe no statistically significant changes for middle and high quality schools. Following for-profit entry, low quality public schools lower paid prices. 


\section{Robustness checks}

Defining the market of competition for for-profit and nonprofit schools is difficult. The very top schools may not be influenced by for-profit entry. We estimate the impact of for-profit expansion excluding the top schools as the first robustness check. The second robustness check tests whether quality changes over time explain the tuition changes. Finally, we provide a robustness check using state and regional measures of for-profit enrollment.

\section{A. $\quad$ Are the top schools different?}

The very top schools may not have any response to the entry of for-profit institutions; acting independently of their entry. These top schools have an established quality that does not require a price signal as for-profit schools enter an area. These schools may also have such a national draw that the CBSA measure of for-profit entry imprecisely measures competition. In tables 5 and 6 we present the results excluding the highest quality schools as measured by our quality index. Table 5 presents the results dropping the top $5 \%$ of institutions (the top 31 schools in our sample) with table 6 looking at the impact of for-profit entry on schools of different quality levels.

Dropping the top $5 \%$ of institutions produces qualitatively and quantitatively similar results. Expanding enrollments in two-year for-profit institutions are followed by increased sticker prices at public two-year schools. As there is expansion of two-year for-profit schools, we find that public schools increase their list prices price to compete directly with the entry. As four-year for-profit schools expand, four-year public schools raise their list price (by slightly more than when the top 5\% are included). And two-year public schools reduce their paid price in response to expanding four-year for-profits.

To see if the highest level two-year and four-year public institutions are impacting this result, we look at the results without the top 1\%, 5\%, 10\%, 25\%, 50\%, and 75\% (table 6). We 
focus on public schools where, as in Tables 2, 3, and 4, we observe price increases in response to for-profit entry. ${ }^{24}$ For the entry of two-year for-profit schools we find that dropping the top 1 percent, 5 percent, and 10 percent of schools increases the impact on two year schools' list price. This impact then diminishes, or becomes insignificant, as we continue to decrease the number of higher quality schools included in the data.

As before, we observe that two-year public schools decreasing list price following fouryear for-profit entry. As we omit the top 1 percent, 5 percent, 10 percent, and 25 percent of schools by quality, the estimated list price response grows.

The bottom panel of Table 6 examines the paid price response of public schools. In the full sample, as four-year for-profits entered, we saw declines in paid price among two year public schools and increases in paid price among four-year public schools. We continue to observe this pattern. However, four-year public schools raise their list price by more as the highest quality institutions are dropped from the samples; the price-increasing behavior appear concentrated in the mid- to lower quality four year public schools.

Focusing on the bottom 25 percent of schools, we see large increases in paid prices at four-year public schools in response to four-year for-profit entry. These lower quality schools may particularly seek to signal their quality difference from for-profits by raising prices. The highest quality schools do not need to send a quality signal through price, and thus appear to respond very little to for-profit entry. Direct price competition between four-year for-profits and two-year public schools appears stronger as we focus on the lower quality institutions.

\section{B. Does quality explain the tuition increases?}

One possible explanation, consistent with price-increasing competition theory, is that existing firms respond to entry by raising quality in costly ways. The resulting higher price may

24 The results for private, non-profits are consistent with the estimates presented in Table 3 and available by request. 
reflect higher quality of services provided. We consider whether the tuition increases solely reflect increases in school quality by adding the quality index as a regressor. We focus on the two-year and four-year school specifications to avoid confounding our definition of high and low quality institutions with changes in school quality over time. The variables used to construct the quality index are available for 2003 to 2009. We estimate the regressions for this shorter sample including and excluding the quality measure as a regressor. Adding the quality index as a regression does not change the estimates on for-profit entry or its interaction with whether an institution offers two year degrees. Although school quality may be changing during this period, it does not explain the changes in listed tuition or real price paid following for-profit entry, at least given our measure of quality. ${ }^{25}$

With substantially lower sticker prices, public schools have less room for price discrimination. However, they can shift their admissions towards out-of-state students and their higher tuition rates. We explicitly consider whether schools respond to for-profit entry by attracting more out-of-state students. Using the same specification as in equation (1) with the fraction of students from out-of-state as the dependent variable, we observe no changes among two-year schools or private schools in the fraction of students from out-of-state. However, fouryear public schools shift towards enrolling more out-of-state students in the wake of expanding for-profit enrollments. This may raise their student quality as well as paid prices. ${ }^{26}$

\section{State and regional measures of for-profit entry}

Throughout our study we have focused on the CBSA as our measure of for profit entry. There are many other measures that can be used as the area of competition for institutions of higher education. We have separately used the MSA, state, and region as the area of enrollment

\footnotetext{
25 These results are suppressed for brevity.

${ }^{26}$ Unfortunately, examining student quality explicitly using measures such as SAT scores is not possible in this sample. Two year schools rarely report or request SAT or ACT scores from their students.
} 
for for-profit schools. The results of these different specifications are similar to the results presented above.

\section{Conclusion}

Although there are many concerns related to higher education, much of the current conversation focuses on two: tuition prices and for-profits. Over the last 20 years there has been a rapid increase in the list price of college. During this same time-period there has also been an expansion of for-profit higher education. Both of these effects have impacted the consumers of higher education and both have been explored independently. However, our research suggests that these two issues are linked: for-profit penetration has a price-increasing impact in higher education. As for-profit institutions enter a given market, high quality public schools respond by increasing their list price, arguably to signal that they produce a higher quality product than the for-profit schools.

This study allows us to expand the literature on price-increasing competition to include higher education pricing in the U.S. As different products develop a diverging quality in their goods, a better understanding of the impacts of price-increasing competition, and empirical examples, help us better understand this impact. The typical CBSA between 1990 and 2009 witnessed about a 125 percent increase in the list price of four year public institutions and a 554 percent increase in for-profit enrollment. We estimate that this increase in for-profit enrollments led public four-year institutions to increase their listed tuition by about $22 \%$. 


\section{References}

Aslanian, Carol B. and David L. Clinefelter. 2012. Online college students 2012: Comprehensive data on demands and preferences. Louisville, KY: The Learning House, Inc.

Aspinwall, Richard C. 1970. "Market Structure and Commercial Bank Mortgage Rates." Southern Economic Journal 36(4): 376-85.

Autor, David. H., Lawrence F. Katz, and Melissa S. Kearney. 2008. "Trends in U.S. wage inequality: Revising the revisionists." Review of Economics and Statistics 90(2): 300-323.

Bagwell, Kyle and Michael H. Riordan. 1991. "High and Declining Prices Signal Product Quality." American Economic Review 81(1): 224-239.

Baum, Sandy. 2011. Drowning in debt: Financial outcomes of students at for-profit colleges [Testimony to the Senate Health, Education, Labor and Pensions Committee]. June 7. Washington, DC.

Baum, Sandy and Jennifer Ma. 2011. Trends in College Pricing, 2011. College Board Advocacy and Policy Center accessed on-line 8/21/2012 at http://trends.collegeboard.org/downloads/College_Pricing_2011.pdf

Baumol, William J. 2012. The Cost Disease: Why Computers Get Cheaper and Health Care Doesn't. New Haven: Yale University Press.

Baumol, William J. and William G. Bowen. 1966. Performing Arts: The Economic Dilemma. New York: The Twentieth Century Fund.

Behrman, Jere R., Mark R. Rosenzweig, and Paul Taubman. 1996. "College Choice and Wages:

Estimates using Data on Female Twins.” Review of Economics and Statistics. 78(4): 672-685.

Bennett, William J. 1987. "Our Greedy Colleges," The New York Times, February 18, 1987.

Black, Dan A. and Jeffrey A. Smith. 2006. "Estimating the Returns to College Quality with Multiple Proxies for Quality.” Journal of Labor Economics 24(3): 701-728. 
Bowman, Nicholas A. and Michael N. Bastedo. 2009. "Getting on the Front Page: Organizational Reputation, Status Signals, and the Impact of U.S. News and World Report on Student Decisions" Research in Higher Education 50:415-436

Caves, Richard E, Michael D. Whinston, and Mark A. Hurwitz. 1991. "Patent expiration, entry and competition in the U.S. pharmaceutical industry: an exploratory analysis.” Brookings Papers on Economic Activity. Microeconomics 1991: 1-66.

Cellini, Stephanie Riegg. 2009. "Crowded Colleges and College Crowd-Out: The Impact of Subsidies on the Two-Year College Market,” American Economic Journal: Economic Policy 1(2), 1-30.

Cellini, Stephanie Riegg and Latika Chaudhary. 2012. "The Labor Market Returns to a For-Profit College Education.”

http://home.gwu.edu/ scellini/Index/Research_files/Cellini\%26Chaudhary_Returns_June1 2.pdf

Cellini, Stephanie Riegg and Claudia Goldin. 2012. "Does Federal Student Aid Raise Tuition? New Evidence on For-Profit Colleges.” National Bureau of Economic Research Working Paper No. 17827.

Chen, Yongmin and Michael H. Riordan. 2007. "Price and Variety in the Spokes Model." The Economic Journal 117 (522): 897-921.

Chen, Yongmin and Michael H. Riordan. 2008. "Price-Increasing Competition.” RAND Journal of Economics 39(4): 1042-1058.

Ching, Andrew T. 2010. "Consumer learning and heterogeneity: Dynamics of demand for prescription drugs after patent expiration.” International Journal of Industrial Organization 28: $619-638$

Chung, Anna S. 2012. "Choice of for-profit college.” Economics of Education Review 31(6): 1084-1101. 
Cornwell, Christopher, David B. Mustard, and Deepa J. Sridhar. 2006. "The Enrollment Effects of Merit-Based Financial Aid: Evidence from Georgia's HOPE Program." Journal of Labor Economics 24(4): 761-786.

Courtemanche, Charles and Art Carden. 2014. "Competing with Costco and Sam's Club: Warehouse Club Entry and Grocery Prices.” Southern Economic Journal 8o(3): 565-585.

Daughety, Andrew F and Jennifer F. Reinganum. 2008. "Communicating quality: a unified model of disclosure and signalling.” The Rand Journal of Economics 39(3): 973-989.

Deming, David J., Claudia Goldin, and Lawrence F. Katz. 2012. "The For-Profit Postsecondary School Sector: Nimble Critters or Agile Predators?” Journal of Economic Perspectives 26(1): $139-64$.

Demsetz, Harold. 1973. "Industry Structure, Market Rivalry, and Public Policy." Journal of Law and Economics 16(1): 1-9.

Dills, Angela K. and Rey Hernandez-Julian. 2008. "Transfer College Quality and Student Performance.” Eastern Economic Journal 34(2): 172-189.

Ehrenberg, Ronald G. 2002. Tuition Rising: Why College Costs so Much. Cambridge, MA: Harvard University Press.

Ehrenberg, Ronald G. 2007. The economics of tuition and fees in American higher education. Retrieved [8/2/12], from Cornell University, ILR School site: http://digitalcommons.ilr.cornell.edu/workingpapers/67/

Ehrenberg, Ronald G. and Susan H. Murphy. 1993. "What Price Diversity?: The Death of Need Based Financial Aid at Selective Private Colleges and Universities." Manuscript of article (shortened) published in Change 25(4): 64-73.

Eide, Eric, Dominic J. Brewer, and Ronald G. Ehrenberg. 1998. "Does it Pay to Attend an Elite Private College? Evidence on the Effects of Undergraduate College Quality on Graduate School 
Attendance." Economics of Education Review 17(4): 371-376.

Frank, Richard G., and David S. Salkever, (1992) "Pricing, Patent Loss and the Market for Pharmaceuticals," Southern Economic Journal 59(2): 165-79.

Frank, Richard G. and David S. Salkever. 1997. "Generic entry and the pricing of pharmaceuticals.” Journal of Economics \& Management Strategy 6(1): 75-90.

Hirschman, Albert O. 1964. “The Paternity of an Index.” American Economic Review 54(5): 761.

Hoxby, Caroline M. 1997. "How the Changing Market Structure of U.S. Higher Education explains College Tuition.” NBER WP\# 6323.

Hoxby, Caroline M. 2009. “The Changing Selectivity of American Colleges.” Journal of Economic Perspectives 23(4): 95-118.

Hurwitz, Mark A., and Richard E. Caves. 1988. "Persuasion or Information? Promotion and the Shares of Brand Name and Generic Pharmaceuticals." Journal of Law and Economics 31(2): 299-320.

Geithman, Frederick E., Howard P. Marvel, and Leonard W. Weiss. 1981. "Concentration, Price, and Critical Concentration Ratios." The Review of Economics and Statistics 63(3): 346-353.

Gerardi, Kristopher S. and Adam Hale Shapiro. 2009. "Does Competition Reduce Price Dispersion? New Evidence from the Airline Industry.” Journal of Political Economy 117(1): 137.

Goldin, Claudia, and Lawrence L. Katz. 2008. The race between education and technology. Cambridge, MA: Belknap Press of Harvard University.

Grabowski, Henry G. and John M. Vernon. 1992. "Brand loyalty, entry and price competition in pharmaceutical after the 1984 Drug Act." Journal of Law and Economics 35(2): 331-350.

Jacob, Brian, Brian McCall, and Kevin M. Stange. 2013. "College as Country Club: Do Colleges 
Cater to Students' Preferences for Consumption?” NBER Working Paper No. 18745.

Keeler, Emmett B., Glenn Melnick, and Jack Zwanziger. 1999. “The Changing Effects of Competition on Non-Profit and For-Profit Hospital Pricing Behavior.” Journal of Health Economics 18: 69-86.

Kessel, Reuben. 1971. "A Study of the Effects of Competition in the Tax-Exempt Bond Market.” Journal of Political Economy 79: 706-738.

Kong Ying. 2004. “The price premium of generic pharmaceuticals to brand-names and pharmaceutical price index." Applied Economics 36(7): 731-737.

Kong, Ying. 2009. "Competition between Brand-Name and generics - Analysis on Pricing of Brand-Name Pharmaceutical.” Health Economics 18: 591-606.

Lamm, R. McFall. 1981. "Prices and Concentration in the Food Retailing Industry.” Journal of Industrial Economics 30(1): 67-78.

Lang, Kevin and Russell Weinstein. 2013. "Evaluation Student Outcomes at For-Profit Colleges." NBER Working Paper NO. 18201

McMillen, Daniel P., Larry D. Singell, and Glen R. Waddell. 2007. "Spatial Competition and the Price of College.” Economic Inquiry 45(4): 817-833.

Marvel, Howard P. 1978. "Competition and Price levels in the Retail Gasoline Market.” Review of Economics and Statistics 6o(2): 252-58.

McPherson, Michael S., Morton Owen Schapiro, and Gordon C. Winston, editors. Paying the Piper. Ann Arbor, MI: University of Michigan Press, 1993.

Monroe, Kent B. "Buyers' Subjective Perceptions of Price.” in Perspectives in Consumer Behavior edited by Harold H. Kassarjian and Thomas S. Robertson, 23-42. Glenview, IL: Scott, Foresman, 1973. 
National Center for Education Statistics. 2013. The Integrated Postsecondary Education Data System: About IPEDS. http://nces.ed.gov/ipeds/about (accessed December 17, 2013).

Nielsen, Helena S., Torben Sørensen, and Christopher Taber. 2010. "Estimating the Effect of Student Aid on College Enrollment: Evidence from a Government Grant Policy Reform." American Economic Journal: Economic Policy 2(2): 185-215.

Peltzman, Sam. 1977. “The Gains and Losses from Industrial Concentration.” Journal of Law and Economics 20(2): 229-63.

Putsis, William P. 1997. "An Empirical Study of the Effect of Brand Proliferation on Private Label - National Brand Pricing Behavior.” Review of Industrial Organization 12(3): 355-371.

Rizzo, Michael and Ronald G. Ehrenberg. 2004. "Resident and Nonresident Tuition and Enrollment at Flagship State Universities." in College Choices: The Economics of Where to Go, When to Go, and How to Pay For It edited by Caroline M. Hoxby, Chicago: University of Chicago Press.

Rothschild, Michael and Lawrence J. White. 1995. "The analytics of pricing in higher education and other services in which customers are inputs.” Journal of Political Economy 103(3): 573586.

Scherer, Frederic M. 1993. "Pricing, profits, and technological progress in the pharmaceutical industry.” Journal of Economic Perspectives 7(3): 97-115.

Scherer, Frederic M. and David Ross. Industrial Market Structure and Economic Performance. $3^{\text {rd }}$ ed. Boston: Houghton-Mifflin, 1990.

Schmalensee, Richard. 1982. "Product Differentiation Advantages of Pioneering Brands.” American Economic Review 72(3): 349-365.

Scott Morton, Fiona M. 2000. "Barriers to entry, brand advertising, and generic entry in the US pharmaceutical industry.” International Journal of Industrial Organization 18(7): 10851104. 
Singell, Larry D. and Joe A. Stone. 2007. "For whom the Pell tolls: The response of university tuition to federal grants-in-aid.” Economics of Education Review 26(3): 285-295.

Stavins, Joanna. 2001. "Price Discrimination in the Airline Market: The Effect of Market Concentration." The Review of Economics and Statistics 83(1): 200-202.

U.S. Census Bureau. 2013. Metropolitan and Micropolitan Statistical Areas Main. http://www.census.gov/population/metro/

U.S. Department of Education, National Center for Education Statistics. (2011). Digest of Education Statistics, 2010 (NCES 2011-015), Chapter 3. http://nces.ed.gov/fastfacts/display.asp?id=76

Ward, Michael B., Jay P. Shimshack, Jeffrey M. Perloff, and J. Michael Harris. 2002. "Effects of the Private-Label Invasion in Food Industries." American Journal of Agricultural Economics 84(4): 961-973. 
Figure 1: Percent of students enrolled in forprofit institutions, 1990-2009

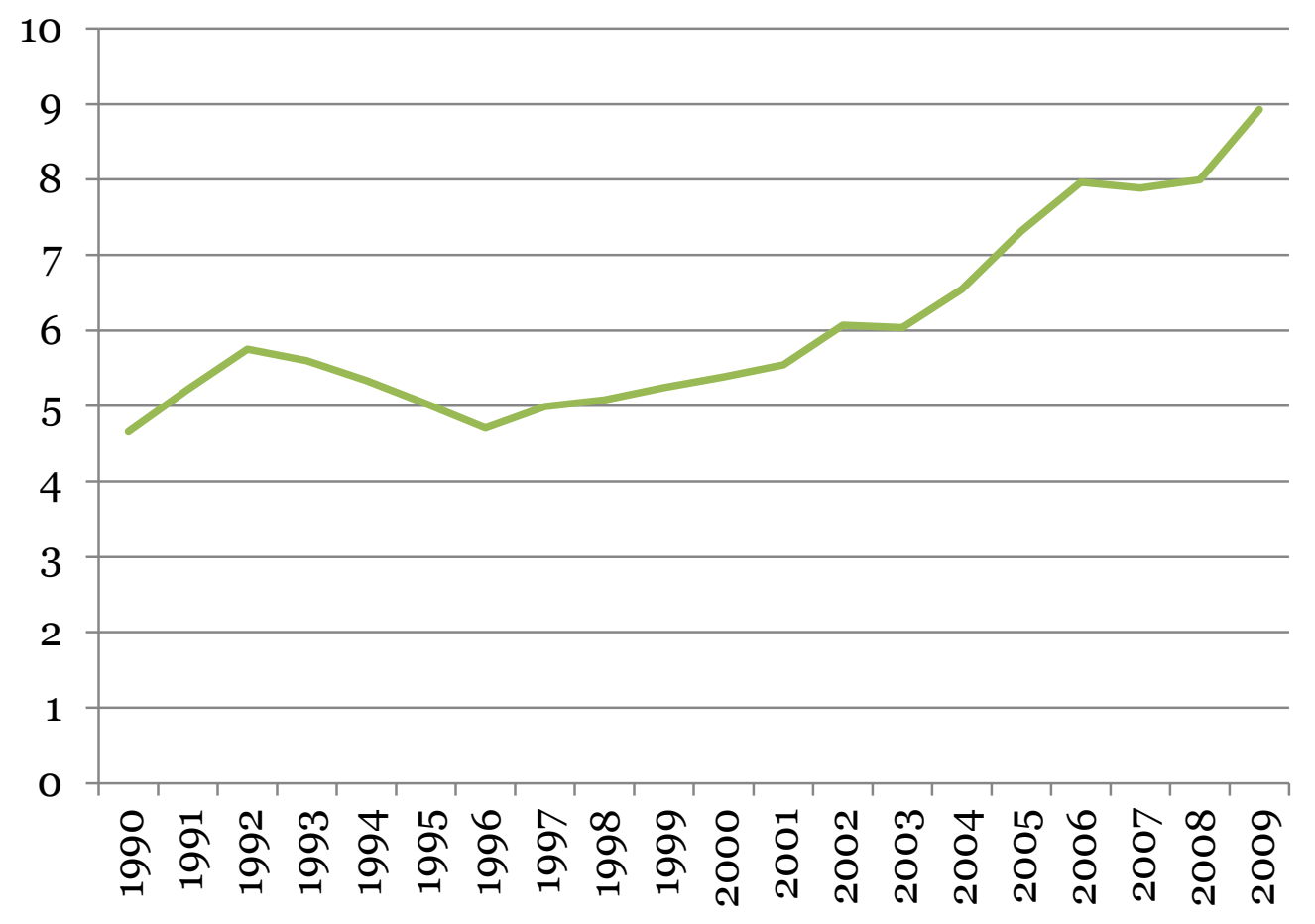


Figure 2: Real listed tuition and fees and growth rate, 1990-2009

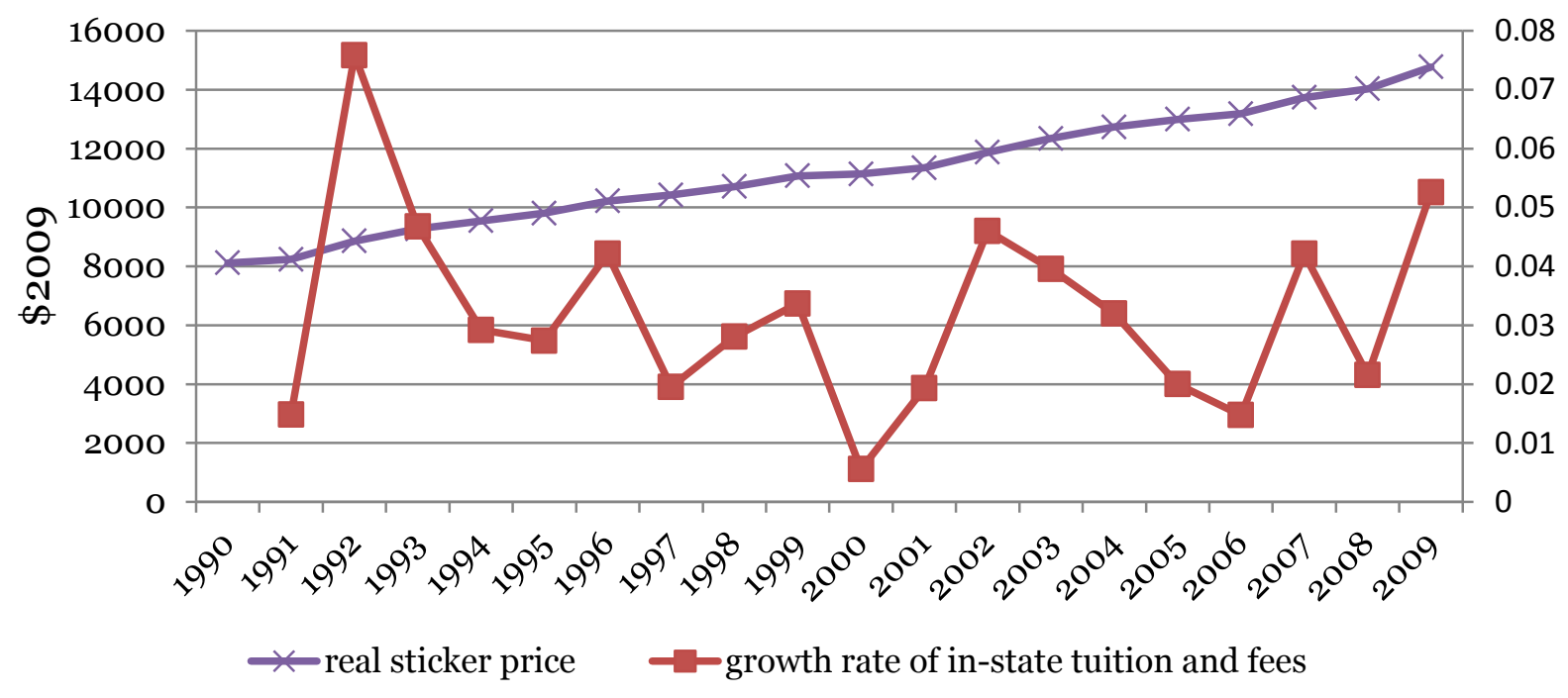


Figure 3: Various measures of real tuition (\$2009), 1990-2009

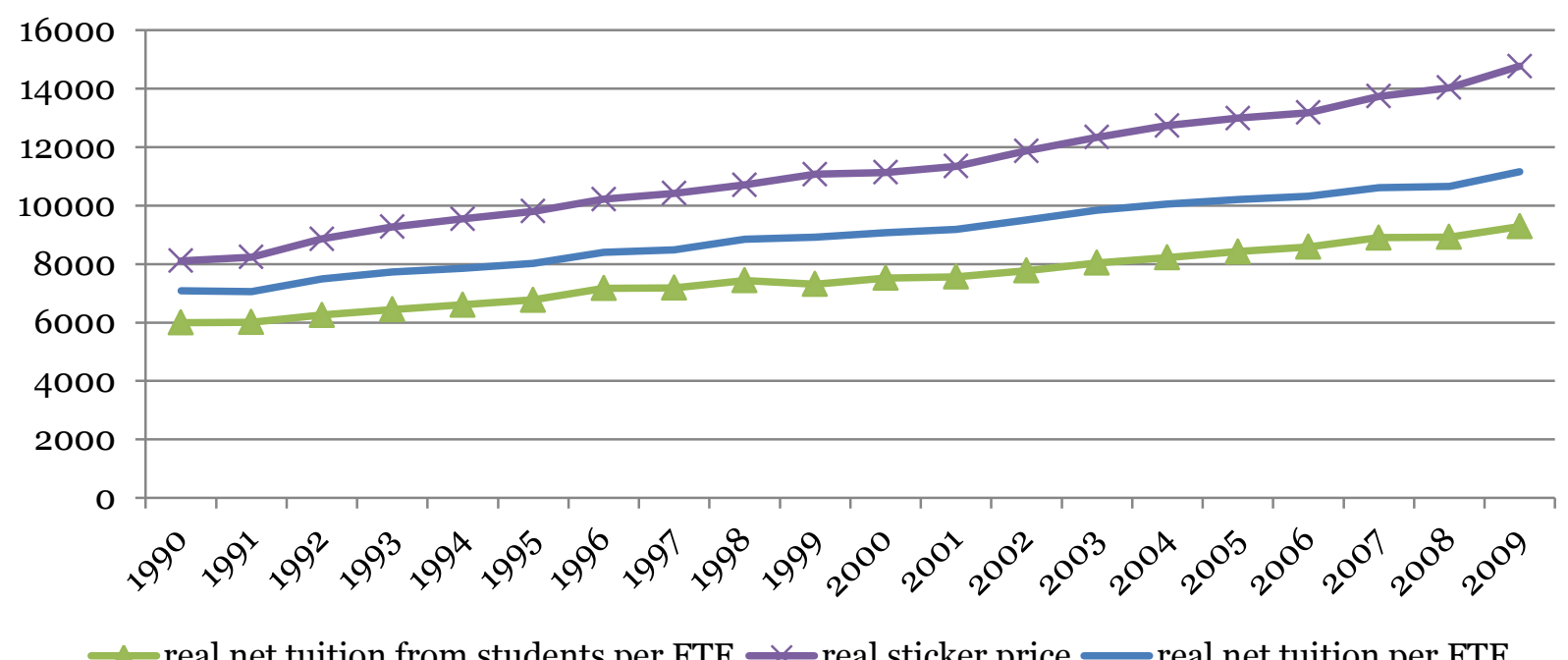


Figure 4: Real tuition by type for four year institutions, 1990-2009

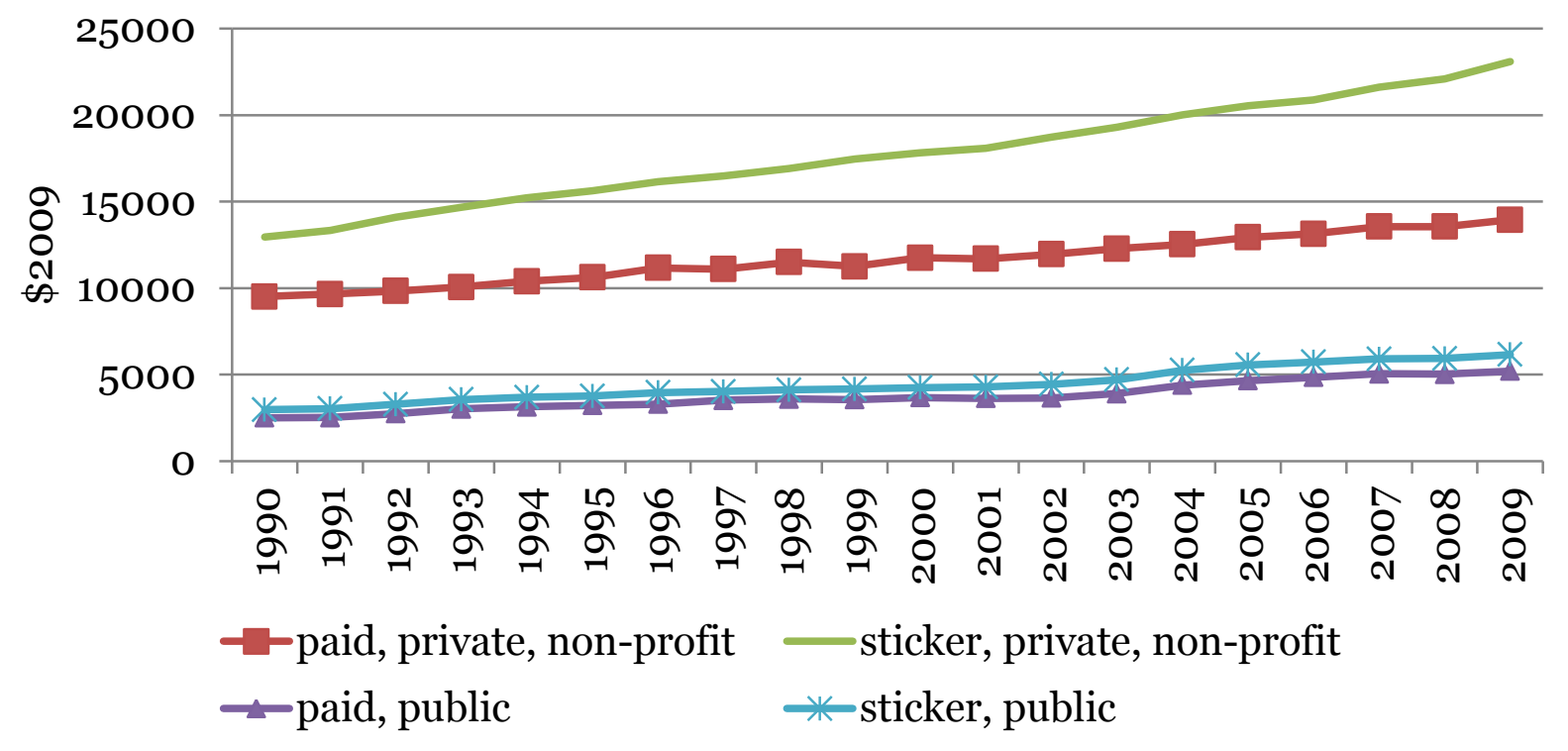


Table 1: Summary Statistics

$$
(n=24,718)
$$

\begin{tabular}{|c|c|c|c|c|}
\hline Variable & Mean & $\begin{array}{l}\text { Std. } \\
\text { Dev. }\end{array}$ & Min & Max \\
\hline In-state tuition (\$2009) & 11297.2 & 8844.8 & 28.9 & 44867.8 \\
\hline Net tuition from students (\$2009) & 7562.9 & 6341.4 & 1.5 & 68557.9 \\
\hline Share of enrollment in for-profits & 0.063 & 0.069 & 0.000 & 0.743 \\
\hline Unemployment Rate & 0.053 & 0.018 & 0.015 & 0.181 \\
\hline CBSA real income per capita (in 000s, \$2009) & 39.166 & 8.071 & 20.222 & 85.068 \\
\hline Percent Hispanic & 0.088 & 0.111 & 0.000 & 0.620 \\
\hline Percent aged 15 to 24 & 0.116 & 0.041 & 0.012 & 0.347 \\
\hline
\end{tabular}


Table 2: OLS regressions of sticker and paid price on fraction of enrollment in for-profit institutions, 1990-2009

\begin{tabular}{|c|c|c|c|c|}
\hline & $\begin{array}{c}(1) \\
\text { private nonprofits } \\
\ln (\text { real sticker } \\
\end{array}$ & $\begin{array}{l}\text { (2) } \\
\text { public } \\
\text { price) }\end{array}$ & $\begin{array}{c}\text { (3) } \\
\text { private nonprofits } \\
\ln (\text { real student } \mathrm{p}\end{array}$ & $\begin{array}{l}\text { (4) } \\
\text { public } \\
\text { id price) }\end{array}$ \\
\hline $\ln (\text { percent for profit })_{t-1}$ & $\begin{array}{c}0.00162 \\
(0.00322)\end{array}$ & $\begin{array}{c}0.0399^{* * *} \\
(0.0129)\end{array}$ & $\begin{array}{c}-0.00259 \\
(0.0118)\end{array}$ & $\begin{array}{c}0.0925^{* * *} \\
(0.0163)\end{array}$ \\
\hline $\ln (\text { percent for profit })_{t-1}{ }^{*} 2$ year & $\begin{array}{c}-0.0335 \\
(0.0247)\end{array}$ & $\begin{array}{c}-0.0405^{* *} \\
(0.0163)\end{array}$ & $\begin{array}{c}0.0556 \\
(0.0551)\end{array}$ & $\begin{array}{l}-0.113^{* * *} \\
(0.0289)\end{array}$ \\
\hline Unemployment Rate & $\begin{array}{l}0.341^{* *} \\
(0.160)\end{array}$ & $\begin{array}{c}0.639 \\
(0.570)\end{array}$ & $\begin{array}{c}1.058 \\
(0.679)\end{array}$ & $\begin{array}{c}0.517 \\
(1.074)\end{array}$ \\
\hline Real per capita income & $\begin{array}{l}0.000410 \\
(0.00107)\end{array}$ & $\begin{array}{l}-0.00349 \\
\text { (o.00435) }\end{array}$ & $\begin{array}{c}0.00979^{* * *} \\
(0.00322)\end{array}$ & $\begin{array}{c}0.00307 \\
(0.00924)\end{array}$ \\
\hline percent Hispanic & $\begin{array}{l}-0.0224 \\
(0.0331)\end{array}$ & $\begin{array}{c}0.224 \\
(0.147)\end{array}$ & $\begin{array}{c}0.0693 \\
(0.0634)\end{array}$ & $\begin{array}{c}-0.360^{* *} \\
(0.160)\end{array}$ \\
\hline percent aged 15 to 24 & $\begin{array}{c}-0.0476 \\
(0.0979)\end{array}$ & $\begin{array}{c}-1.108^{* *} \\
(0.492)\end{array}$ & $\begin{array}{l}-0.529^{*} \\
(0.282)\end{array}$ & $\begin{array}{l}-0.497 \\
(0.515)\end{array}$ \\
\hline Observations & 12,750 & 9,724 & 12,750 & 9,724 \\
\hline R-squared & 0.785 & 0.600 & 0.207 & 0.247 \\
\hline Number of unitid & 847 & 675 & 847 & 675 \\
\hline
\end{tabular}

All regressions include CBSA-level unemployment rate, real income per capita, the fractions of the population that is Hispanic, and the fraction of the population aged 15 to 24. Year dummies, institution fixed effects, and CBSA trends included in all regressions. Standard errors in parentheses. ${ }^{* * *} \mathrm{p}<0.01,{ }^{* *} \mathrm{p}<0.05,{ }^{*} \mathrm{p}<0.1$ 
Table 3: OLS regressions allowing the effect of for-profit enrollment share to differ based on degrees offered at for-profit

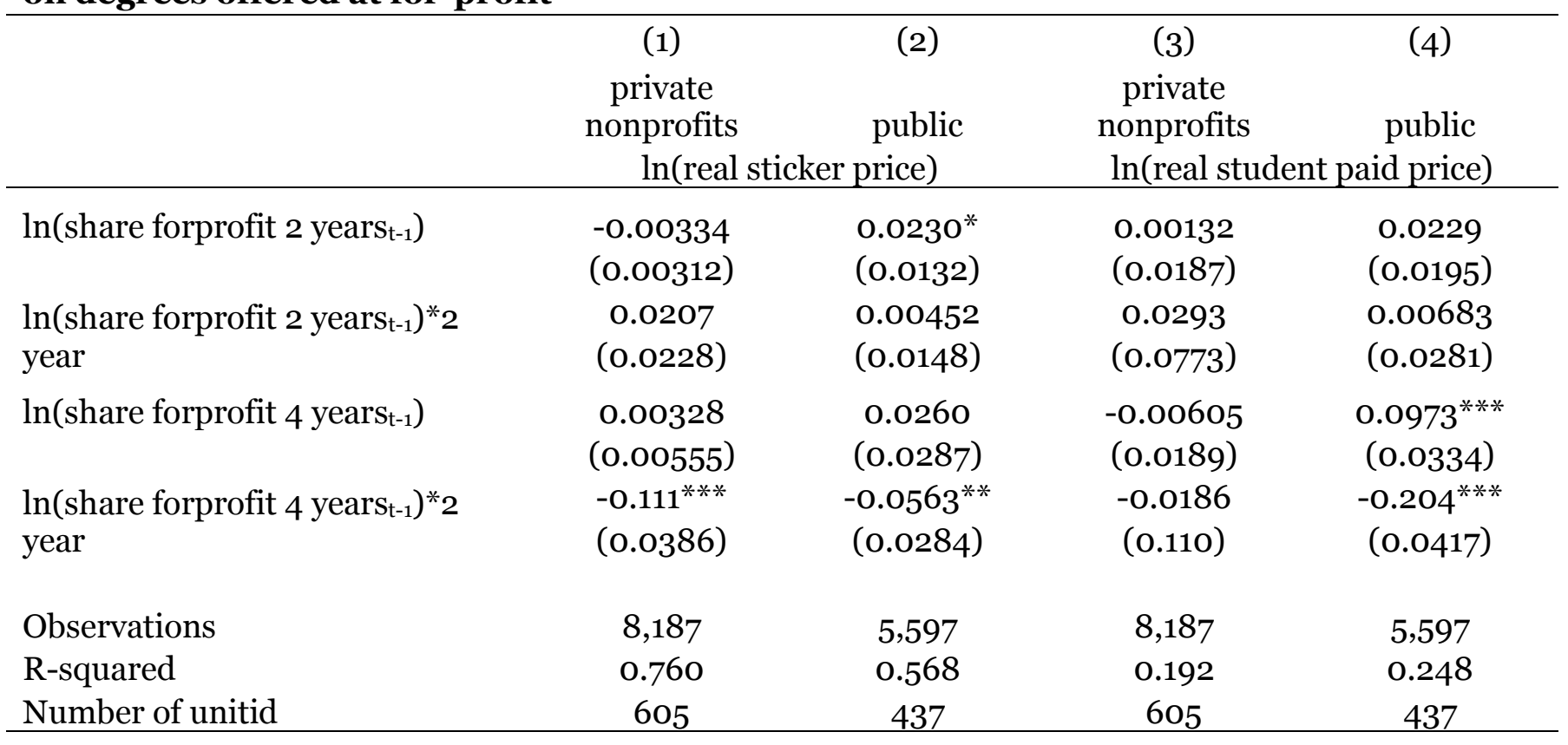

All regressions include CBSA-level unemployment rate, real income per capita, the fractions of the population that is Hispanic, and the fraction of the population aged 15 to 24. Year dummies, institution fixed effects, and CBSA trends included in all regressions. Standard errors, clustered by CBSA, in parentheses. ${ }^{* * *} \mathrm{p}<0.01,{ }^{* *} \mathrm{p}<0.05,{ }^{*}$ $\mathrm{p}<0.1$ 
Table 4: OLS regressions of sticker and paid price on fraction of enrollment in for-profit institutions, 1990-2009

\begin{tabular}{|c|c|c|c|c|}
\hline & $\begin{array}{r}\text { (1) } \\
\text { private nonprofits } \\
\ln \text { (real }\end{array}$ & $\begin{array}{l}\text { (2) } \\
\text { public } \\
\text { rice) }\end{array}$ & $\begin{array}{c}\text { (3) } \\
\text { private nonprofits } \\
\ln \text { (real stu }\end{array}$ & $\begin{array}{l}\text { (4) } \\
\text { public } \\
\text { price) }\end{array}$ \\
\hline $\ln (\text { percent for profit })_{t-1}$ & $\begin{array}{c}0.00974 \\
(0.00680)\end{array}$ & $\begin{array}{c}-0.00801 \\
(0.0107)\end{array}$ & $\begin{array}{l}0.00646 \\
(0.0164)\end{array}$ & $\begin{array}{c}0.0472 \\
(0.0342)\end{array}$ \\
\hline $\ln (\text { percent for profit })_{t-1} *$ high & $\begin{array}{c}-0.0157^{*} \\
(0.00825)\end{array}$ & $\begin{array}{c}0.0256^{* *} \\
(0.0114)\end{array}$ & $\begin{array}{l}-0.0106 \\
(0.0197)\end{array}$ & $\begin{array}{l}-0.00671 \\
(0.0383)\end{array}$ \\
\hline $\ln ($ percent for profit $))_{\mathrm{t}-1}{ }^{*}$ low & $\begin{array}{l}-0.100 \\
(0.164)\end{array}$ & $\begin{array}{c}-0.628^{* * *} \\
(0.0319)\end{array}$ & $\begin{array}{c}-0.195 \\
(0.603)\end{array}$ & $\begin{array}{l}-2.321^{* * *} \\
(0.0808)\end{array}$ \\
\hline Observations & 11,305 & 4,000 & 11,305 & 4,000 \\
\hline R-squared & 0.839 & 0.868 & 0.238 & 0.520 \\
\hline Number of groupid & 716 & 261 & 716 & 261 \\
\hline
\end{tabular}

All regressions include CBSA-level unemployment rate, real income per capita, the fractions of the population that is Hispanic, and the fraction of the population aged 15 to 24. Year dummies, institution fixed effects, and CBSA trends included in all regressions. Standard errors, clustered by CBSA, in parentheses. ${ }^{* * *} \mathrm{p}<0.01,{ }^{* *} \mathrm{p}<0.05,{ }^{*} \mathrm{p}<0.1$ 
Table 5: OLS regressions of sticker and paid price on fraction of enrollment in for-profit institutions excluding the top 5 percent, 1990-2009

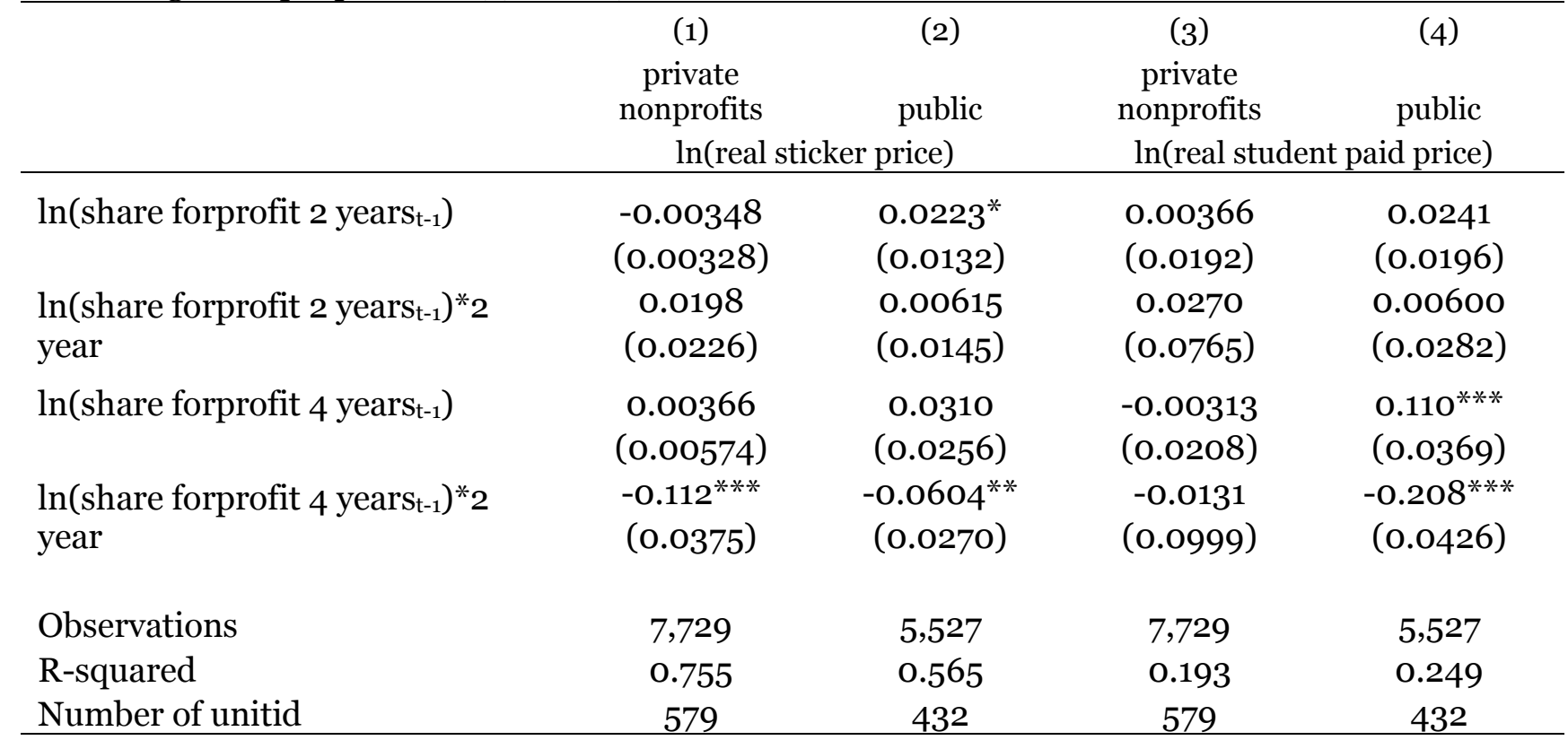

All regressions include CBSA-level unemployment rate, real income per capita, the fractions of the population that is Hispanic, and the fraction of the population aged 15 to 24 . Year dummies, institution fixed effects, and CBSA trends included in all regressions. Standard errors, clustered by CBSA, in parentheses. 
Table 6: Effect of for-profit entry on two-year and four-year schools, by public college quality percentile

\begin{tabular}{|c|c|c|c|c|c|c|}
\hline & $\begin{array}{c}(1) \\
\text { bottom } 99 \%\end{array}$ & $\begin{array}{c}(2) \\
\text { bottom } 95 \%\end{array}$ & $\begin{array}{r}\text { (3) } \\
\text { bottom 90\% } \\
\text { List }\end{array}$ & $\begin{array}{l}\text { (4) } \\
\text { bottom } 75 \% \\
\text { Price }\end{array}$ & $\begin{array}{c}\text { (5) } \\
\text { bottom } 50 \%\end{array}$ & $\begin{array}{c}(6) \\
\text { bottom } 25 \%\end{array}$ \\
\hline $\ln \left(\right.$ share forprofit 2 years $\left.\mathrm{t}_{\mathrm{t}-1}\right)$ & $\begin{array}{c}0.0215 \\
(0.0136)\end{array}$ & $\begin{array}{c}0.0184 \\
(0.0138)\end{array}$ & $\begin{array}{c}0.0160 \\
(0.0156)\end{array}$ & $\begin{array}{c}0.0208 \\
(0.0156)\end{array}$ & $\begin{array}{c}0.0302 \\
(0.0223)\end{array}$ & $\begin{array}{c}0.0776 \\
(0.0522)\end{array}$ \\
\hline $\ln \left(\text { share forprofit } 2 \text { years } t_{t-1}\right)^{*} 2$ year & $\begin{array}{l}0.00889 \\
(0.0163)\end{array}$ & $\begin{array}{c}0.0122 \\
(0.0170)\end{array}$ & $\begin{array}{c}0.0157 \\
(0.0192)\end{array}$ & $\begin{array}{c}-0.000837 \\
(0.0192)\end{array}$ & $\begin{array}{c}0.000485 \\
(0.0228)\end{array}$ & $\begin{array}{c}-0.0441 \\
(0.0469)\end{array}$ \\
\hline $\ln \left(\right.$ share forprofit 4 years $\left.\mathrm{y}_{\mathrm{t}-1}\right)$ & $\begin{array}{c}0.0353 \\
(0.0267)\end{array}$ & $\begin{array}{c}0.0363 \\
(0.0286)\end{array}$ & $\begin{array}{c}0.0362 \\
(0.0301)\end{array}$ & $\begin{array}{l}0.0485^{* *} \\
(0.0208)\end{array}$ & $\begin{array}{c}0.0246 \\
(0.0252)\end{array}$ & $\begin{array}{c}0.0421 \\
(0.0827)\end{array}$ \\
\hline $\begin{array}{l}\ln \left(\text { share forprofit } 4 \text { years }{ }_{t-1}\right) * 2 \text { year } \\
\text { R-squared }\end{array}$ & $\begin{array}{c}-0.0656^{* *} \\
(0.0277) \\
0.569\end{array}$ & $\begin{array}{c}-0.0666^{* *} \\
(0.0278) \\
0.561\end{array}$ & $\begin{array}{c}-0.0689^{* *} \\
(0.0278) \\
0.563\end{array}$ & $\begin{array}{c}-0.0731^{* *} \\
(0.0296) \\
0.655\end{array}$ & $\begin{array}{c}-0.0395 \\
(0.0266) \\
0.650\end{array}$ & $\begin{array}{c}-0.0401 \\
(0.0851) \\
0.612\end{array}$ \\
\hline & bottom 99\% & \multicolumn{5}{|c|}{ Paid Price } \\
\hline $\ln ($ share forprofit 2 yearst-1 $)$ & $\begin{array}{c}0.0243 \\
(0.0198)\end{array}$ & $\begin{array}{c}0.0209 \\
(0.0218)\end{array}$ & $\begin{array}{c}0.0183 \\
(0.0234)\end{array}$ & $\begin{array}{c}0.0334 \\
(0.0346)\end{array}$ & $\begin{array}{c}0.0460 \\
(0.0528)\end{array}$ & $\begin{array}{l}-0.108 \\
(0.120)\end{array}$ \\
\hline $\ln \left(\text { share forprofit } 2 \text { years } t_{-1}\right)^{*} 2$ year & $\begin{array}{l}0.00857 \\
(0.0278)\end{array}$ & $\begin{array}{c}0.0134 \\
(0.0295)\end{array}$ & $\begin{array}{c}0.0224 \\
(0.0308)\end{array}$ & $\begin{array}{l}0.00826 \\
(0.0437)\end{array}$ & $\begin{array}{c}0.0205 \\
(0.0568)\end{array}$ & $\begin{array}{l}0.179^{*} \\
(0.102)\end{array}$ \\
\hline $\ln \left(\right.$ share forprofit 4 years $\left.\mathrm{t}_{\mathrm{t}-1}\right)$ & $\begin{array}{l}0.0999^{* * *} \\
(0.0357)\end{array}$ & $\begin{array}{l}0.102^{* * *} \\
(0.0383)\end{array}$ & $\begin{array}{l}0.105^{* * *} \\
(0.0387)\end{array}$ & $\begin{array}{l}0.112^{* *} \\
(0.0550)\end{array}$ & $\begin{array}{l}0.203^{*} \\
(0.106)\end{array}$ & $\begin{array}{l}0.453^{* * *} \\
(0.109)\end{array}$ \\
\hline $\ln \left(\text { share forprofit } 4 \text { years } t_{-1}\right)^{*} 2$ year & $\begin{array}{c}-0.208^{* * *} \\
(0.0424)\end{array}$ & $\begin{array}{l}-0.210^{* * *} \\
(0.0437)\end{array}$ & $\begin{array}{l}-0.213^{* * *} \\
(0.0453)\end{array}$ & $\begin{array}{l}-0.185^{* * *} \\
(0.0655)\end{array}$ & $\begin{array}{c}-0.243^{* *} \\
(0.114)\end{array}$ & $\begin{array}{l}-0.601^{* * *} \\
(0.0672)\end{array}$ \\
\hline R-squared & 0.248 & 0.254 & 0.253 & 0.252 & 0.280 & 0.384 \\
\hline $\begin{array}{l}\text { Observations } \\
\text { Number of unitid }\end{array}$ & $\begin{array}{c}5,497 \\
429 \\
\end{array}$ & $\begin{array}{c}5,316 \\
418 \\
\end{array}$ & $\begin{array}{c}5,002 \\
396\end{array}$ & $\begin{array}{c}3,721 \\
298 \\
\end{array}$ & $\begin{array}{c}1,940 \\
169 \\
\end{array}$ & $\begin{array}{c}832 \\
77 \\
\end{array}$ \\
\hline
\end{tabular}

